\title{
Accentual Doublets in Standard Languages in the Neo-Štokavian Base: Bosnian Standard Accentuation with a Focus on the Accentuation of Verbs
}

\begin{abstract}
Contemporary Bosnian normative accentuation shares common features with Croatian, Montenegrin, Serbian and Serbo-Croatian standard, and therefore in order to determine precisely which elements of the orthoepic norm are Bosnian, it should be considered above all in its own context. However, due to discrepancies, instabilities, and root variation, the task of establishing the principles of an efficient orthoepic norm remains a difficult one, unless such a solution were to tolerate a wide variety of accentual variants. This paper studies accentual doublets of verbs in the Bosnian standard. To this end, it is particularly important to assume a contrastive-comparative perspective, by evaluating varying usage in the standard languages with a Neo-Štokavian base.
\end{abstract}

\section{Keywords}

accentual doublets, normative accentuation, Bosnian language, verbs

\begin{abstract}
Abstrakt
Współczesna bośniacka norma akcentuacyjna ma cechy wspólne ze standardowymi odmianami języków chorwackiego, czarnogórskiego, serbskiego i serbochorwackiego. Dlatego aby precyzyjnie określić, które elementy normy ortoepicznej są bośniackie, należy ją rozpatrywać przede wszystkim w odniesieniu do niej samej. Z uwagi jednak na niespójności, niestabilności i wariantywność formy rdzeni trudno jest ustalić reguły skutecznej normy ortoepicznej, chyba że takie rozwiązanie zakładałoby tolerancję dla dużej liczby wariantów akcentowych. Niniejszy artykuł podejmuje problem czasownikowych dubletów akcentowych w standardowej odmianie języka bośniackiego. W tym
\end{abstract}


celu należy przyjąć podejście kontrastywno-komparatystyczne, poprzez porównanie różnych przykładów użycia w językach standardowych opartych na podstawie nowosztokawskiej.

\section{Słowa kluczowe}

dublety akcentowe, akcentuacja normatywna, język bośniacki, czasowniki

\section{Introduction}

Since accentual doublets in language use have a direct link to the concept of language norm, which views them as necessary, admissible, or as a compromise solution to a certain degree, the study of doublets will become an axis in the analysis of accentual norm of the contemporary language. The reason for this is that anything that remains outside this topic is to be considered an established, stable, and readily recognizable part of the entirety of the language in question.

Regarding linguistic differences, we do not mean dialect variation that is present in the wider, non-Bosnian territory. They are rather viewed as a bundle of various factors that are potentially relevant for a well-established contemporary Bosnian accentual norm, including dialectal factors, even though the entirety of Bosnia is Neo-Štokavian ${ }^{1}$ or Neo-Štokavianized. $^{2}$ However, examples will be given illustrating e.g. differences between East Štokavian and West Štokavian influences, ${ }^{3}$ the difference between usage and

${ }^{1}$ Accentual norms of all standard languages that are based on Štokavian take newer Štokavian dialects as their foundation (Neo-Štokavian). From a dialectological perspective, the Neo-Štokavian Ijekavian speech belongs to the East Herzegovina dialect, the NeoŠtokavian Ikavian speech belongs to the West Herzegovina dialects while the Neo-Štokavian Ekavian speech belongs to the Šumadija-Vojvodina dialect. The so-called classical norm is Vuk-Daničić's accentual system based on the accents that Vuk Karadžić and Đura Daničić offered in their respective reference books. However, it is well-known that Karadžić, while setting the standard for the Serbo-Croatian language, adopted numerous speech characteristics of both the Bosnian and the Croatian South. Despite all that, there are credible deviations (albeit minimal) from Vuk's language, namely, in accent (generally, everything that is NeoŠtokavian is also relevant for the standard), but that is a broader topic.

${ }^{2}$ As for the Bosnian territory, only the South has a full and original Neo-Štokavian accentual system, whereas other parts acquired distinct Neo-Štokavian characteristics from the South, so that we will call them Neo-Štokavianized. Thus, even nowadays we find some OldŠtokavian accentuation in the Northwest, the North, and the Northeast of Bosnia, i.e. in the West Bosnian, East Bosnian and the Posavina dialects of the Bosnian language.

${ }^{3}$ The Štokavian territory is traditionally divided into so-called East and West Štokavian. That, however, is not in direct relation to the Eastern and the Western form of the SerboCroatian standard language (with the Serbian and the Croatian language respectively). In fact, in the medieval period, a majority of the Bosnian territory was West Štokavian. $15^{\text {th }}$-century migrations led to the mixing of East and West Štokavian in the Bosnian territory. The bound- 
norm, analogy in accentuation, or principles of accentuation in relation to a certain territory. Accentual doublets in the Bosnian language, i.e. those validated by usage or by theory, require more in-depth research in order to render a comprehensive view of the actual state of the contemporary Bosnian orthoepic norm.

This research is especially needed if we consider the language norm as a sociolinguistic issue, in particular, normative accentology, which is significantly more representative of the language system than e.g. the lexical layer. Hence, the study of Bosnian accentuation needs to be oriented towards itself, discovering and acknowledging those of its aspects that are inherently Bosnian. Only after this is achieved can questions of Eastern or Western influence $^{4}$ be considered. A comparative-contrastive analysis will certainly help serve this purpose.

However, at this stage a re-examination and cataloguing of language usage is needed, because every aspect of the Bosnian accentuation system first needs to be evaluated from a purely Bosnian perspective. This requires dialectology to serve only as a framework, whereas initial research must primarily rely upon normative reference books (see Section 2) as well as contemporary language use.

Inconsistency is a recurring feature in normative reference books and accentology and Bosnian ones are no exception. Therefore, a comparative and contrastive analysis of Bosnian reference works is needed at this initial stage, with the particular aim of putting forward satisfactory solutions in relation to contemporary speech practice.

\section{On normative accentology and doublets in standard language}

It is well-known that the principles of normative accentology were established in the Serbo-Croatian period and that the contemporary situation requires reorientation with regard to those principles. From the early 1960s onwards, the standard language has seen multiple proposals in accentology:

ary between the East and West Štokavian is not clear nowadays. However, it is assumed that it extends southwards near the valley of the Neretva river, and northwards somewhere west of the Drina river. It is also the case that Serbian is based on East Štokavian dialects, Croatian on West Štokavian, whereas within the Bosnian territory both East and West Štokavian dialects are spoken.

${ }^{4}$ By this we mean the territorial dominance of East Štokavian or West Štokavian speech characteristics (which meet in the Bosnian territory), but not only and not necessarily the influence of either Croatian, Montenegrin or Serbian on the language in Bosnia and Herzegovina. 
"Not all of our words have identical accents in the entirety of the Serbo-Croatian territory... Entire classes of similar words show accentual variation" (Jonke 1965: 225). ${ }^{5}$ Accentual doublets are not considered an anomaly, as shown in another note from that period:

It is a completely natural occurrence that a standard language based on the spoken form of the vernacular, with its mobile word stress in [derivationally] related words and in forms belonging to the paradigms of inflectionable words, has a high number of accentual doublets. (Vuković 1972: 56; emphasis mine)

While establishing the principles that might help determine the Bosnian standard, one needs to take into consideration the inconsistencies, discrepancies, and instabilities that characterize the contemporary accentual norm (cf. Martinović 2014). It follows that doublets will stem from the relationship between usage and theoretic norm and between the East and West Štokavian accentual patterns (taking into account the Southern dialect in particular). Moreover, doublets also emerge from adherence to certain territorial centers, analogy in accentology, the degree of detachment from the Serbo-Croatian tradition, etc.

However, the very principles of the orthoepic norm and normative accentology in general go in several different directions, with some communities relying on mass usage as a point of reference, and others selecting welleducated speakers of the language as the model. Regardless of what is taken as a benchmark, it is based on literary/standard language. If we were to dismiss this criterion because of Vuk's arbitrary definition that started to be accepted throughout the entire South Slavic territory after the Vienna Literary Agreement (when the Southern dialect was accepted as the standard), we ought to bear in mind that, as regards accentology as a system, the main characteristic of these dialects is in fact the innovative Neo-Štokavian accentuation (with four accents, accent retraction onto the proclitic and postaccentual length), which can, in essence, accommodate all speech variants of contemporary language.

Paying close attention to the variety that lies at the foundation of the standard as an important (albeit not the only) source of the contemporary orthoepic norm, we must highlight the following:

In order to address one of the toughest questions in the standardization of the SerboCroatian literary language, namely, the question of the standardization of the literary accent, it is necessary to identify the status of accent in speech that lies at the foundation of the literary language in the first place. Despite great contributions in that field, I think it essential to first identify accent in selected localities where speakers practice literary accentuation. These should include those places that are cultural

\footnotetext{
${ }^{5}$ All translations of passages originally in South Slavic are mine.
} 
and economic centers of their respective regions, and as such represent centers for the dissemination of speech features. In this regard, features of speech that are displayed by residents of Mostar are of great importance for the region of Herzegovina. As a cultural and economic center of Herzegovina, Mostar plays a major role, which is why the speech of its residents is a major factor in spreading its speech characteristics in the entire region. (Matijašić 1964: 337)

Apart from emphasis on "one of the toughest questions in standardization" it is important to recognize that the features characteristic of the Herzegovinian variety, even if not considered critical, compete in the standard contemporary language with those that deviate from the Herzegovinian orthoepic norm. Needless to say, here we do not consider speech practices that can be taken as a model by a speech community, but rather selected speech practices that can resolve particular questions and principles in orthoepy (e.g. accent shift, ${ }^{6}$ post-accentual length, relationship between quantity and quality in different word groups, etc.). One of the approaches to the validation of usage of accentual doublets in contemporary language is the model whereby anything that has been accepted in Neo-Štokavian speech can be/is also accepted in contemporary language:

Our standard language encompasses all the prosodic richness that Neo-Štokavian speech practices have to offer. In other words, anything that is alive in NeoŠtokavian speech practices can be accepted as Neo-Štokavian accentual standard... (Peco 1987: 246)

However, this statement refers to accents that do not deviate from predetermined rules in accent distribution. Peco further lists several examples of accentual doublets which he claims belong to the standard variety, noting that:

The question of sequence of the listed accents should not represent a problem. If two accents are given as equal members of the accentual system, the sequence is not important. Everybody will use the accent they feel is more common. (Peco 1987: 247; emphasis mine)

In the light of the Bosnian standard, this could be connected to the principle that anything that is not common in Bosnia should also not be in use or referenced as a relevant accentual variant form (that is, as it is no longer part of the common standard accent), i.e. only what is inherent in Bosnian Neo-Štokavian speech practices - and not what is found in Neo-Štokavian speech in general or what is common throughout the Neo-Štokavian region - should be accepted.

\footnotetext{
${ }^{6}$ In view of the extent and importance of the debate on accent shift, which concerns both lexical structure and sentence structure, we do not deal with it in this paper.
} 
As regards the precedence of one variant over another, let us note Aleksandar Belić's interesting view which considers this issue in relation to socalled varieties with literary (standard) accentuation:

Needless to say, our language features words that have two correct accentual doublets; sometimes, although less commonly, even three (cf. zâdruga and zädruga (cooperative, noun), etc.). Efforts to make the most prominent accentual pattern in a certain territory in which people speak in the literary accent need to be supported. (Belić 1971: 89; emphasis mine)

In other words, notes by scholars of accentology on valid and correct accentual doublets start early on, when Belić (1971) highlights the tendency to make standard one variant form, i.e., the one that is closer to speakers using the literary/standard accent, which is, in fact, (innovative) Neo-Štokavian. On the other hand, it is more natural to use the accent that is more representative of a given territory:

Of two (less commonly, three) accepted accent patterns, the one that is most common in the areaneeds to be used. (An unusual accent - even if it is correct - will be deemed incorrect by listeners, and will distract them, and divert them from what you are saying). (Telebak 2009: 47)

However, since it is possible to opt for a standardized, accepted accentual doublet confirmed by usage in a wider Štokavian territory, we will single out the notion of valid accentual doublets and regard them as pronunciation variants that are not primarily tied to a particular variety in a narrow sense. ${ }^{7}$ The focus of study in this paper are doublets that are attested in a wider territory.

\section{Resources for the study of Bosnian orthoepic standard}

Aside from works discussing the standardization of accentuation in the former Serbo-Croatian language, more recent literature on the Bosnian orthoepic norm includes dictionaries and grammar books, as well as reference books devoted to accent. There have been two reference books of the latter kind so far: Bulić (2009) and Alić (2017).

Some of the earliest systemic solutions to Bosnian accentology can be seen in Jahić, Halilović, Palić (2000) and in Riđanović (2012), as well as in $\mathrm{RBF}, \mathrm{RBJ}$, and RBI. ${ }^{8}$ Also invaluable for Bosnian orthoepy is the work by Asim Peco (cf. 1987, 1988, 2007).

${ }^{7}$ Idiolect, regionalism, subdialect framework, etc. It is only the narrow tier that does not require a direct relation to innovative speech practices with Neo-Štokavian accent.

${ }^{8}$ Needless to say, a resource of particular value is the six-volume BHDK. 
Bulić (2009) offers even more examples of accentual doublets. Out of nearly 10,000 entries in his dictionary, almost 400 are accentual variants of another entry, so they are registered as accentual doublets (across different parts of speech), whereas nearly 600 are potentially variable (even though their doublets are not listed as an option). What follows from this is that nearly $10 \%$ of Bulić's dictionary falls into the category of accentual doublets in the contemporary language. In general, Bulić's (2009) accentuation follows traditional prescriptive rules, which makes the doublets all the more valuable.

Moreover, literature in contemporary Bosnian shows accentual doublets in over 6,000 examples in base forms only, ${ }^{9}$ which makes up $10 \%$ of the 60,000 entries (based on average Bosnian dictionary data). When entire paradigms are considered, the database is even bigger.

Riđanović (2012) offers, in his chapter on grammar, a detailed overview of the Bosnian accent in all its categories across several parts of speech. ${ }^{10}$ He notes that Bosnian, in relation to other South Slavic languages, still preserves a classical accentual system, which distinguishes it from other languages (cf. Riđanović 2012: 5). ${ }^{11}$ In principle, he aligns accentuation with the root variant (e.g. rising intonation of the jat sound, or falling intonation of sounds outside the first syllable, etc.), while quoting several characteristic accentual variants.

Numerous examples of doublets in Bosnian standardized accentuation can also be found in Alić (2017) and Jahić, Halilović, Palić (2000).

\section{Bosnian accentual doublets}

A more comprehensive study of accentual doublets requires investigation of qualitative and quantitative differences between them by analyzing occurrence, tendencies and principles in accentuation, or specific categories that are connected with the emergence of particular variantss.

The previous section gave an overview of the corpus that has been utilized for the study of Bosnian accentual doublets. However, it needs to be pointed

\footnotetext{
${ }^{9}$ Excerption for a future Dictionary of accentual doublets in contemporary Bosnian language as part of and one of the findings in the project Accentual doublets in contemporary Bosnian language carried out by Sarajevo University's Language Institute since February 2017.

${ }^{10}$ It is interesting to note that foreigners are given the information that Bosnian accents can also be found in the 1987 Serbo-Croatian-English dictionary by Morton Benson, although the accents do not always correspond to Riđanović's (2012: 284).

${ }^{11}$ Moreover, this observation was made earlier in a special paper authored by Riđanović and Aljović (2009), which further emphasizes the difference between the Bosnian accentual system and the one in other South Slavic languages respectively: "In particular, the accents and the accentual patterns described in this article are largely absent outside Bosnia-Herzegovina” (Riđanović and Aljović 2009: 87).
} 
out that the topic has also been the focus of more recent studies and articles, e.g. Bulić (1999), Valjevac (2005, 2009a, 2009b), Meco (2009), Kalajdžija (2009), Klimentić (2011), Šehović (2013), Kadić (2014), Hodžić (2014, 2016, 2017, 2019) or Hodžić and Ćatović (2018). These issues are also more frequently discussed in international literature, e.g. Zec (2005), Riđanović and Aljović (2009), Talić (2015a, 2015b), Franks (2017), etc.

Šehović (2013) gives an in-depth analysis of the falling intonation in the initial syllable and interprets the results in the light of Bosnian dictionaries (where a distancing from traditional views on the matter of standardization is shown in dictionaries). Moreover, Šehović (2013) shows accents in words with long jat and points out how Bosnian dictionaries still hold traditional views on the accent of long jat (except for RBF, which makes a distinction in examples with rising intonation, e.g. traditional mlijèko 'milk' vs. newer mlijéko 'milk'). However, we believe that there is no justification for not making a distinction in the other word group with jat too, as has been done in Croatian accentual standard. This view is supported by a questionnaire and further theoretical explanations in Hodžić and Ćatović (2018), albeit bearing in mind that jat with long falling intonation can also have a third rendering. That third variant is rather close to an actual realization attested in speech (long falling intonation) which combines short falling intonation with unstressed length (this view is held by Riđanović 2012 in his grammar book).

It is interesting to note that Riđanović (2012) marks examples of jat with a falling intonation (in different parts of speech) as short falling intonation with post-accentual length. Such occurrences constitute $2 \%$ of examples in BHDK, whereas ones with long falling intonation constitute $5 \%$ of all examples (see Hodžić and Ćatović 2018). ${ }^{12}$ Jahić (2000) comments with regard to such variants that there is "no unstressed post-accentual length in the standard language" (Jahić 2000: 14). Examples with short falling intonation followed by post-accentual length (in places where long falling intonation is found in speech) are certainly perceived as closer to examples with long falling intonation. It follows that the view held by Riđanović (2012), i.e., the rendering of words with falling intonation, is closer to contemporary speech in practice, because:

There can be certain deviations in the perception of speech practice. It may well be that examples of short falling accent in words with long jat can also be found in contemporary language (as in cases in the Bosnian-Herzegovinian dialectological complex where the realization of that form in speech does not significantly differ from the long rising intonation in place of post-accentual length. (Hodžić and Ćatović 2018: 415)

${ }^{12}$ Examples with diphthongs were not considered in this case. Those amount to $20 \%$ of all examples. 
However, variant solutions should be considered in the first place, such as:

(1) sïjeno/sïjēno/sijêno 'hay', brïjeg/brïjēg/brijêg 'hill', snïjeg/snïjēg/snijêg 'snow', bïjel/ bïjēl/bijêl 'white', rïječcrijiečc/rijêč 'word', lïjep/lijeêp/lijêp 'beautiful', slijjep/slijep/ slijêp 'blind', vïjek/vijjek/vijêk 'century', etc.

Riđanović (2012) postulates falling intonation outside the first syllable for words such as:

(2) adekvätan 'adequate', asistënt 'assistant', dirëktan 'direct', elegäntan 'elegant', egzäktan 'exact', interesäntan 'interesting', pedäntan 'meticulous', perfëktan 'perfect', etc.

Dictionaries of Bosnian show short rising intonation in such words (occurring instead of falling intonation, or moved to initial word position). The short falling intonation pattern is also valid, but only as a second-choice variant (RBJ; RBF), whereas patterns admitting only short rising intonation can also be found (where short falling intonation appears outside the first syllable, or it is moved to the front of the word, as in RBI). However, there are a number of exceptions in some examples ${ }^{13}$ where short falling intonation is not even registered, but examples with short rising intonation in initial word position are found instead, e.g. ègzaktan (RBF) 'exact', pèdantan (RBI) 'meticulous', direktan (RBF) 'direct', etc., alongside short falling intonation as in ädekvātan (RBI) 'adequate.'

The situation is similar in cases where Riđanović (2012) gives long falling intonation outside the first syllable as the dominant pattern, as in:

(3) generâtor 'generator', radijâtor 'radiator', kompilattor 'compiler', ventilâtor 'fan', etc.

Dictionaries of Bosnian offer the forms of genèrātor and generâtor (RBF and $\mathrm{RBJ})$ or just genèrātor (RBI).

Moreover, in the light of deviations from the standard form, a general remark made by Pranjković (2010) is that the Bosnian language should see a slight deviation from the standard, stated as:

In the light of accentual norm in standard Bosnian, I think that the situation is different as that standard, rightly so, relies on a "Central Štokavian" dialect more than is the case with Croatian. Therefore, it is justified that the standard is in the "Martić style." (Pranjković 2010: 23)

However, as in Croatian, in Bosnian we can also speak of certain falling intonations outside the first syllable that should be at least "allowed as doublets" (Pranjković 2010: 22). The same statement is made (also) in reference

${ }^{13}$ They are not listed as an option by dictionaries. 
to Bosnian, in which it is "unreasonable to insist on classical accents on long versions of jat, e.g. snïjeg 'snow' or mlijèko 'milk'” (Pranjković 2010: 23), bearing in mind that "a consistent Neo-Štokavian (central) accentual system with frequent and consistent shifts of accent to initial word position and with numerous post-accentual lengths" are not seen as "representative of regional, rural, or even (especially in recent years) Serbian accentuation" in Bosnia (Pranjković 2010: 19). This is even more so in Croatia. It is the Bosnian standard that preserves the classical accent to a major extent. This, however, should not be taken for granted. The reality is that the Bosnian standard does not allow for radical deviations that would affect the system as a whole. However, with due respect to the principles and the number of models that render an accent valid, the Bosnian standard will certainly be able to undergo a fundamental revision of its accentual norm.

By accentual doublets dealt we do not mean in this paper general accentual variations and alternations (in morphologically conditioned accent shifts, for example). The fact that "[c]ertain alternations that we find in grammar books and dictionaries of our language are not present in the contemporary standard Bosnian language" (Alić 2017: 155) does not mean a smaller number of doublets per se. The fact of the matter is that certain established and wellknown accentual doublets in other territories will, of course, not be inherent in the Bosnian language. However, comprehensive research into the accentual standard (with due respect for the principles of orthoepy) will show a more dominant presence of accentual doublets in the contemporary Bosnian language. Such research will reveal new principles, trends, and tendencies in compliance with accepted valid (Bosnian) accentual doublets. ${ }^{14}$

The specific state of contemporary Bosnian accentology highlights the qualitative-quantitative relationships, problem areas, and individual differences. In that light it is important to point out and focus on the qualitative properties of short and long accents, the quantitative properties of falling and rising intonation, the accentuation of words based on foreign roots, the accent of long jat, the question of post-accentual length, the question of accent placement, etc.

Considering accentual doublets in other parts of speech, the relationships are shown in the following examples (merely as an overview):

(4) màma/mäma 'mother', svàdba/svädba 'wedding', àuto/äuto 'car', ïgra/ìgra 'game', svjètlo/svjëtlo 'light', povèćalo/povećálo 'magnifying glass', šiljalo/šiljálo 'sharpener', njüška/njúška 'snout', krǐška/krîška 'slice', mëntor/mentor 'mentor', kï̌ma/kîčma 'spine', kćî/kćî 'daughter', lepèza/lepéza 'fan', rakèta/rakéta 'rocket',

${ }^{14}$ This is mentioned in relation to the dominant Neo-Štokavian and Neo-Štokavianized Bosnian speech practices in which different local markers of speech (that are not only local and narrow in a dialectological sense) will be "candidates" for normative accentuation. 
ekipa/ekípa 'team', pràvac/právac 'direction', bèbica/bébica 'little baby', ülāz/ ùlaz/úlaz 'entrance', cŕnac/cr̀nac 'black man', bánka/bânka/bänka 'bank', dèsētka/ dèsetka 'ten', pròpis/própis 'regulation', ìgračke/ìgrāčke 'toys', sandále/sàndale 'sandals', etc.;

(5) mène/mènē/mëne 'me', tèbe/tèbē/tëbe 'you', sèbe/sèbē/sëbe 'oneself', tàkav/tàkāv 'such', njègov/njegōv 'his', njézin/njézīn/njêzin 'her', ôn/ön 'he';

(6) blïstav/blistav 'brilliant' jäsan/jàsan 'clear', lägan/làgan 'easy', lètimičan/lëtimičan 'cursory', mòćan/möćan 'powerful', limen/lïmen 'tinny', stäklen/stàklen 'glassy', lèden/lëden 'icy', dòkon/dökon 'leisurely', gläsan/glàsan 'loud', lèžêran/lëžéran 'casual', mácin/mácīn 'cat's';

(7) nòcas/nòćās 'tonight', dànas/dànās 'today', veòma/vèoma/vëoma 'very';

(8) jedànaest/jedànaēst 'eleven', dvánaest/dvánaēst 'twelve', čètvrtì/čètvrittī 'fourth';

(9) dákle/däkle/däklē/dâklēe/dàklē/dáklē ‘so', kàda/käda/kàdā 'when';

(10) bârem/bärem/bárem/bàrem 'at least', mòžda/möžda 'maybe'. ${ }^{15}$

\subsection{Accentual doublets in verbs}

The distinctive variable nature of accents in infinitive verb forms, in which rising intonation is considered closer to Vuk's and Daničić's views, is largely captured in Bosnian reference works by listing variant forms. Alternatively, only forms with falling intonation are given in words with long tones, such as doći 'come', naći 'find', poći 'leave', vući 'pull', rasti 'grow', tresti 'shake', kleti 'curse', etc. Also, in similar compound verbs - nadoći 'increase', naići 'come across', navući 'put on', porasti 'grow', istresti 'shake out', zakleti 'swear' - a fixed 'rising' intonation will also be closer to Vuk's and Daničić's views (cf. Daničić 1925).

In Bulić (2009) variant forms with long falling intonation are given as the first option: nâći and náći 'find', svûći and svúći 'pull off', tûći and túći 'beat',

${ }^{15}$ The examples shown are also valid both according to normative literature and Bosnian speech practice (personal notes), but here they are further systematized. The goal here is to give a clear overview of the strong presence of accentual doublets across parts of speech in contemporary Bosnian, with a focus on verbs in particular. Doublets in verbs are validated in Matijašić (1964) and a preliminary questionnaire in Hodžić (2017), but also in the wider literature on dialectology (cf. Peco 2007). Needless to say, after having systematized the accentual doublets, a further systematically well-developed questionnaire on contemporary speech practice is required. Such a research project could also encompass language heard on the radio and on television (which remains beyond the scope of this paper). For now, the corpus of accentual doublets with audio recordings of different pronunciations for over 1,000 common words in the Bosnian language can be found at https://www.e-bosanski.ba/rad/ (accessed January 16, 2020) 
vûći and vúći 'pull', zâći and záći 'go behind'. Furthermore, nadići $i^{16}$ and nàdīći 'exceed' are given, but only izāći 'go out', òbūći 'clothe', òbići 'bypass', òtīći 'leave', and prêći 'cross'. RBF in principle gives only examples with falling intonation: dôci 'come', klêti 'curse', râsti 'grow', prêci 'cross', svû́ci 'pull off', vîći 'pull', trêsti 'shake', snâći 'manage', but cf. nâći (náći) 'find', ûći (úći) 'enter'. The following forms are also present: prèteći (preteći) 'overtake', nàtaći (natàci) 'pull on', òteći (otèci) 'swell', dòreći (dorèci) 'finish', òbreći (obrèći) 'promise', but only pròteći 'flow'. RBI offers variant forms with falling intonation as the first option: pâsti/pásti 'fall', prêci/préći 'cross', prối ipróći 'pass', râsti/rásti 'grow', svûći/svúci 'pull off', trêsti/trésti 'shake', but dóći/doći 'come', úći/ûći 'enter', and only tûći 'beat', klêti (se) 'swear'. Also given are doublets: òbići/obići 'bypass', prònāći/pronáći 'find', pòrāsti/porásti 'grow', pòdrāsti/podrásti 'grow in', ponàrāsti/ponarásti 'grow', prèrāsti/prerásti 'outgrow', but only òtīći 'leave', izāći 'exit', òbūći (se) 'clothe', dòtūći 'beat', dòvūći 'drag over', istrēsti (se) 'shake out', dòrāsti 'rise to something', izrāsti 'outgrow', nàrāsti 'grow', òbrāsti 'overgrow', poòdrāsti ' grow up', prìrāsti 'grow on', pròrāsti 'sprout', zàrāsti 'cicatrize', etc.

If we are considering questions of potential dominance of one variant form over another and potential causes of the occurrence of doublet forms in general or their spread in actual language use, the following illustration offers deeper insights.

It is highly likely that the diffusion of doublets with rising intonation is a result of migrations (East Bosnian and East Herzegovinian, and the territory of Krajina). However, this should not be taken for granted, because of differences between some older and newer accentual patterns.

Moreover, in his Bosnian grammar Riđanović (2012) postulates both rising and falling intonation in rasti 'grow', pasti 'graze', tresti $i^{17}$ 'shake', i.e., in doći 'come', preći 'cross', zaći 'go behind', poći 'set out', proći 'pass', naći 'find', etc. On this group of verbs, he notes (2012: 293): "The rising tone in disyllabic perfectives derived from ići (go) is typical of northwestern Bosnia and generally sounds more elegant; I myself use the falling tone." The same author also offers doublets in examples with short rising accent in the first syllable

${ }^{16}$ With fixed accent as the first option.

${ }^{17}$ In the present tense, these three words do not have a long vowel. On this issue Riđanović notes: "The final vowel of present-tense stems is long, except in e-conjugation verbs with a monosyllabic present-tense base bearing a rising accent." He gives the following examples: teče 'flows', krade 'steals' (Riđanović 2012: 297), but indicates length in razlikuje 'distinguishes', pakuje 'packs', raduje 'exults', imenuje 'names', interesuje 'interests', zakuje 'nails', pokupuje 'buys up', putuje 'travels' (and also in other instances, where length is indisputable/common: pozdravi 'greets', napravi 'makes', uradi 'does', telefonira 'phones', organizira 'organizes', govori 'speaks', kleveće 'swears', razveseli 'cheers up', gomila 'accumulates', kahveniše 'has coffee', etc.) 
and length in the second syllable, or with a long rising accent in the second syllable, as in derivatives from the verb ići (go), e.g.: izići (izaći) 'exit', obići 'walk around', otići 'go away', nadići 'go beyond', podići 'go under', razići 'disperse', uzići (uzaći) 'go up', and in nadoći 'rise', pridoći 'come, join later', pronaći 'find out', proizaći 'result from', zaobići 'go round', etc. (Riđanović 2012: 293-294). ${ }^{18}$

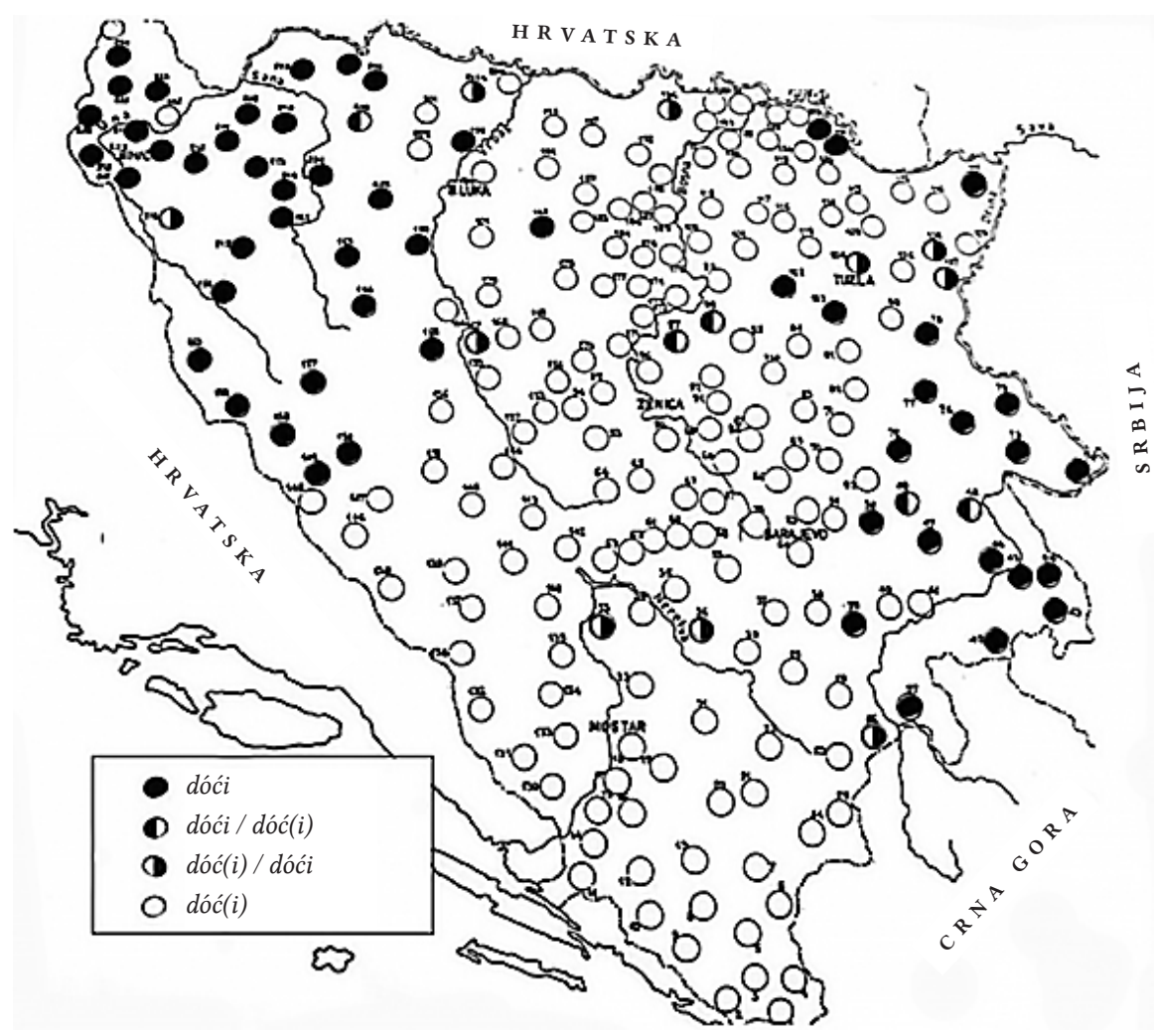

Fig 1. The dissemination of accentual variants of the infinitive verb form doći (according to BHDK). Map made by the author. ${ }^{19}$

Examples with differences in quality of short accents (thereby also differences in place of accent in derivatives) are given in a different order in Bulić (2009), which results in dotàci and dòtaći 'touch'; istàci and istaći 'emphasize', dotèći and dòteći 'reach out', and with a reversed order: dòmoći and domòći 'get hold of something', dòvesti and dovèsti 'bring', but only ùmaći 'escape'.

\footnotetext{
${ }^{18}$ Similarly, BHDK offers üzèla/uzéla 'she has taken' and dóci/dóci 'come', etc.

${ }^{19}$ I would like to thank Naila Valjevac and Haris Ćatović for the prepared material.
} 
Furthermore, Bulić (2009) offers tàći 'touch', whereas maći 'move' and reći 'say' are not listed. ${ }^{20}$

Čedić (2010) generally prefers falling intonation in root forms, i.e.: täći 'touch', mäći 'move', rëći 'say', but: tëći/tèci 'flow'. However, the following doublets are also present: dòtaći/dotàci 'touch', pritaći/pritàci 'attach', but only: pòdstaći 'encourage', pòtaći 'motivate', ùtaći 'plug in', zàtaći 'tuck'. Also, variation is registered in dòteći/dotèci 'reach out', pòteći/potèći 'flow', prèteći/pretèci 'overtake', zàteći/zatèći (se) 'find', but only isteći 'expire', nàteći 'swell', òteći 'swell', priteći 'come to', ùteći 'flee', stëći 'acquire'. Derivatives from mäći 'move' do not have doublets except for a single example, omàći 'slip'. Hence, we have izmaći 'slink off', nàmaći 'earn', òdmaći (se) 'move away', pòmaći 'move', poòdmaći 'advance', prèmaći 'displace', primaći 'move closer', ùmaći 'escape', ùzmaći 'recede'. The verb rëći 'say' yields the following doublet forms: pòreći/porèći 'deny', zàreći/zarèci se 'swear', and forms with rising tone in the base: takoréci 'so to speak', rèčen 'said', and derivatives with a shifted accent: dòreći 'finish', izreći 'pronounce', òdreći (se) 'renounce', opòreći 'deny', pròreći 'foretell', ùreći 'put a spell on somebody'.

RBF mostly lists doublets in their root form, with precedence given to rising intonation, which is sometimes the only option. Hence, there are dóci (dối) 'come', kléti (klêti) 'swear', but only náci 'find'. However, derivatives show only one variant: nàdōći 'increase', nàdrāsti 'overgrow', dòvūći 'drag over'. Also, there is only màci 'move', but nàmaći (namàci) 'earn', izmaći-izmakla 'slink off); and only dòtaći 'touch', nàtaći 'put on', istaći 'emphasize', dòteći 'eke out', isteći 'expire', nàteći 'swell', dòreći 'finish', izreći 'pronounce', etc.

Regarding short tone in root forms, Peco (2007) (on the dialect characteristics of Ortiješ near Mostar, cf. Peco 2007: 407) highlights falling intonation as the main difference with regard to Daničićs infinitive accents with rising intonation. This does not apply to all other Bosnian speech practices, since, as has been pointed out, short tones have rising intonation in most cases. Bearing this in mind, we could speak of a sequence of doublet examples in the infinitive form in the Bosnian language, i.e., of the necessity of including forms with short falling accent where preference is given to rising ones in the infinitive, or vice versa. ${ }^{21}$ Besides the forms already mentioned: reći 'tell', leći 'lie down', taći 'touch', maći 'move', the following examples are also included: igrati 'play', kasniti 'be late', šapnuti 'whisper', kahnuti 'cough', lanuti 'bark', krojiti 'taylor', cuclati 'such on something', crtati 'draw', blinka$t i$ 'blink', pustiti 'let go of', ići 'go', zboriti 'tell', etc. For all the word forms

${ }^{20}$ Only examples that were considered to pose a potential dilemma have been listed. Hence, there is no complete solution.

${ }^{21}$ Note that Peco (2007) only mentions verbs of the former group, whereas in this paper we discuss accent in the infinitive in general (where one of the potential solutions is standardization by accent on the present infinitive form). 
mentioned, both the rising and falling intonation is possible, although the doublets are sometimes listed and sometimes not. Even though there are instances in which doublet forms are not taken into account, but precedence is given to rising intonation, we think that in this case priority should be given in Bosnian to accentuation departing from Daničić's rising accents.

Furthermore, considering accentual doublets in Bosnian verb forms, there are also interesting examples of differences in the quality of rising tones in infinitive forms. These are found throughout the present tense, e.g. kóštati 'cost', klizati 'slide', žúljati 'scratch', (za)ruméniti 'flush', (za)crvéniti 'flush', (po)rédati 'arrange', govóriti 'speak', etc. In actual speech practice, these words can also have short rising accent. ${ }^{22}$

Here the difference according to the same principle in the vocalic $r$ is well known, e.g.: (pre)trpjeti 'suffer', (za)crnjeti (se) 'go black', (do)grdjeti 'be fed up with', (po)srkati 'slurp', posrnuti 'stumble', (po)tvrditi 'confirm', prevrnuti 'upturn', šmrcati 'sniffle', etc. These can have both short rising and long rising accent.

There are also examples with differences in both quality and quantity: štítiti/štïtiti 'protect', báciti/bäciti 'throw', ćápati/ćäpati 'snatch', tábati/ täbati $i^{23}$ 'patter', etc.; or kârtati (se)/kàrtati se 'play cards', etc.

There are a number of infinitive forms with long reflexes of jat for which, besides the traditional rendering, preference can be given to doublets in practice, e.g., cijeniti 'cherish', dijeliti 'share', lijepiti 'paste'. It turns out that this category also renders a number of accentual doublets (if we accept both solutions). ${ }^{24}$

There are also doublets in the perfect (i.e., active verbal adjective particularly in the first person plural and third person singular): králi/kräli 'they stole' and krála/kräla 'she stole', píili/pïli 'they drank' and píla/pïla 'she drank', bráli/bräli 'they plucked' and brála/bräla 'she plucked', even in

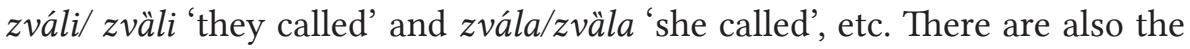

${ }^{22}$ In all contemporary Bosnian dictionaries we find only, e.g., kóštati 'to cost', kôštām 'I cost', kóštānje 'costing' (according to RBF, RBI and RBJ) whereas the second edition of RBI lists only the doublet forms kòštānje/kóštānje 'costing' but not the verb kòštati 'to cost'and kòštām 'I cost' (which is found in Rječnik Matica '60, i.e., as a variant alongside kóśtati 'to cost'). The latter form is well present in Bosnian speech practice, in the South specifically. In Krajina (northwest), however, the form köštati 'to cost' and köštām 'I cost'can be heard, which is listed in some dictionaries of the Croatian language.

${ }^{23} \mathrm{With}$ the remark that the approach to doublet forms in this group of examples is also different. RBF and RBI, e.g., list báciti 'throw' whereas Bulić (2009: 37) lists báciti and bäciti, etc., and RBJ báciti (bäciti). Some dictionaries of contemporary Bosnian language, however, does not list täbati 'tapper' (but only tábati, with utábati 'tread' following logically, but not ùtabati). Also, RBF lists štititi 'protect'and RBI štítiti/štïtiti.

${ }^{24}$ At least until a complete shift to doublets in speech practice is made, or traditional, literary forms are dismissed. 
following examples: sàvila/sävīla 'she bent', prèdala/prëdāla 'she delivered/ submitted', pròzvala/prözvāla 'she called out', etc.

Compound verb form doublets are also known. They are mostly distributed from north to south even though those forms can be found in specific speech practices as in examples with the active verbal adjective in feminine form: pröčitāla 'she read', üpoznāla 'she met', vjërovāla 'she believed', küpovāla 'she bought', pöčešljāla 'she combed', etc. The reason for these doublets is the omission of post-accentual length in forms of the present tense or accent shift to the left in compound verbs. ${ }^{25}$

The presence or absence of post-accentual length can be traced in different parts of speech. Particularly interesting is the difference in the pronunciation of verbs in which, besides a change in tone and duration (vowel quality and quantity), we find a shift in (post-accentual) length as well. Čirgić and Šušanj (2013: 25-27) indicate length in Montenegrin forms that cannot be found in their Bosnian cognates, as in the dative, instrumental and locative cases of nouns, e.g.: pjësmāma 'through songs' and 'to the songs', grupāma 'by groups', rïbāma 'to the fish'; also in infinitive forms of some verbs: skìnūti 'unclothe', mr̈znūti 'freeze', slüšāti 'listen', glëdāti 'watch', pjëvāti 'sing', küpìti 'pick', rüšiti 'demolish', tr̈sīti 'get rid of', vjërovāti 'believe', škölovāti 'educate', or in the passive verbal adjective: skïnūla 'she unclothed', glëdāla 'she watched', vjërovāla 'she believed'. ${ }^{26}$

Therefore, when, e.g., Delaš (2013: 37) ${ }^{27}$ marks that there are some long accentual doublets in verb forms like pročitati 'to read' and pročitām/ pröčitām 'I read' (due to the inability to make a difference between falling and rising short accents in the root form), we think that there is a connection with similar cases in non-prefixed forms e.g.: vjërovāti 'to belive' and vjërovāla 'she believed', škölovāti 'to educate' - škölovāla 'she educated'. Be that as it may, there is variation, i.e., potential presence of doublets, ${ }^{28}$

${ }^{25}$ The following forms need to be mentioned here: sävīla 'she bent', prëdāla 'she submitted', prözvāla 'she called out', pröčitāla 'she read', vjërovāla 'she believed', küpovāla 'she bought'.

${ }^{26}$ Also, so-called secondary length is mentioned in Peco (1988), where, besides other forms, the following ones can be found: gödināma 'through the years', mötkāma 'by poles', knjïgāma 'by books' ... (cf. Peco 1988: 156).

${ }^{27}$ Speakers who do not make a difference between rising and falling accents in verbs formed by prefixation tend to hypercorrectly shift the rising accent onto the prefix. Hence, instead of using forms like pročitati 'to read' and pročitām 'I read', prepòznati 'recognize' and prepòznām 'I recognize' they tend use pröčitati 'to read' and pröčitām 'I read', prëpoznati 'recognize' and prëpoznām 'I recognize', pöbacati 'throw away' and pöbacām 'I throw away', etc. However, such speakers will never make a shift towards the syllable that comes before the stressed one. (Delaš 2013: 37).

${ }^{28}$ Kapović (2018) offers a detailed explanation for his resources on accent of active verbal adjective forms where (diachronically) differences are shown in primary and secondary accentual forms. Later (synchronically) many speech practices partly or fully converge, i.e., 
in root forms too, which amounts to the question of whether the falling accent is shifted onto the proclitic or not, and at the same time the question of the already existing lengths in some cases. This results in doublets in verbal derivatives. Thus, we have slüšăla 'she listened' and glëdāla 'she watched' from glëdāti 'watch' and slüšāti 'listen'. Also, prèslušāla 'she listened', prègledāla 'she watched' and prègledati/-la 'watch/ed' from glëdati 'to watch' and glëdala 'she watched', prèslušati/-la 'listen' from slüšati 'to listen' and slüšala 'she listened', etc.

Thus, prefixed forms like pröčitāla 'she read', prëpoznāla 'she recognized', pöčešljāla 'she combed' can also be discussed in the light of an analogical connection with the aforementioned examples that feature secondary length. It follows that we speak about doublets in different examples of verbs and not only about the retraction of falling accents onto the proclitic.

One should also mention the well-known variation in terms of omission or preservation of post-accentual length, which also applies to Bosnian verbs. In verbs with rising intonation, but also in some other examples - e.g., ùspijem 'I succeed', čüjem 'I hear', plètem 'I knit', šijem 'I stitch', rädujem 'I rejoice', pöpijem 'I drink', donèsem 'I carry' (see Matijašić 1964: 354) - length is omitted in southern usage, whereas it is common with some northern varieties to omit length in present verb forms as in bèrem 'I pluck', sabèrem 'I gather', ubèrem 'I pluck', pèrem 'I wash', opèrem 'I wash', ispèrem 'I rinse' (cf. RBF). There are doublets with a long vowel but also with falling accent and length (in the root), e.g., bërēm 'I pluck', përēm 'I wash'.

Similarly, aorist verb forms also have doublet forms. Hence, southern dialects commonly have üdarī 'hit', ìskočì 'jumped out', prëlomī 'break', ügledā 'noticed', whereas more to the north the vowel is short. Moreover, aorist forms without length are also characteristic of the Bosnian South, e.g., pročìta 'read', odàzva 'responded', preùda 'remarried', obàsja 'illuminated', zadřža 'retained', uzòra 'ploughed', upòzna 'met', prepòzna 'recognized', zapísa 'wrote', opróba 'tasted', zavíka 'shouted', etc.; also to be found are

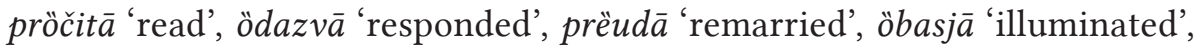
$z a ̈ d r z ̌ \bar{a}$ 'retained', üzorā 'ploughed', üpoznā 'met', prëpoznā 'recognized',

they affect one another (see Kapović 2018: 257). Furthermore, Kapović (2018) gives preference (significantly but inconsistently) to standardization of accentual types exemplified by bjëžāla 'she escaped' in the dialect usage of Piva and Drobnjak. This, furthermore, supports our conclusion regarding this type of accentuation with examples from Montenegrin (see Čirgić and Šušanj 2013: 25-27). However, among authentic diachronic forms are also examples like örālo 'plough', kövālo 'forge'; but not òralo, kòvalo (see Kapović 2018: 257). Hence, it can be concluded that there is no one-sided type of accentuation and that (also) in contemporary Bosnian language both types of accentuation can be expected with active verbal adjectives. This, in fact, happens in practice (which is also confirmed in the Bosnian dialectological complex). 
zäpīs $\bar{a}$ 'wrote', öprōbā 'tasted', zävīka $\bar{a}^{29}$ 'shouted', etc. (cf. Matijašić 1964: $359-365) .^{30}$

Besides the examples and categories listed, some variability in accentuation of verbs can be found in other examples of single infinitive forms, as well as in different examples of prefixed verbs, etc.

\section{Conclusions}

The Bosnian accentual standard should, in any case, be tolerant towards a greater number of valid accentual variants spread across parts of speech, especially in regard to validated variants.

In addition to established accentual variation (falling accent outside the first syllable, the accent of jat, words of foreign origin, the question of postaccentual length, etc.) there is more variability in Bosnian, which usually manifests itself in the opposition between quality and quantity in base forms (with invariable forms). The number of doublets will rise with further analysis of accentual forms in morphologically conditioned shifts in accent.

Doublets in contemporary Bosnian accentology are also found in the verb system. The most pronounced examples concern the ratio between the numbers instances of different qualities of short and long accents in the infinitive of some verbs (and in accordance with the aforementioned, to differences in accentuation in derived verb forms when the accent is shifted leftwards). Doublets are also visible in issues of usage of post-accentual length (most frequently in the present and aorist), and in dilemmas with the place of the accent (especially in relation to the ratio of quality and the issue of post-accentual length) in some word forms. Beside the infinitive, the present, and the aorist, significant doublet numbers are also found in different examples of the active verbal adjective (hence, also in forms of the perfect).

There is also a certain drift away from the accentuation of Vuk-Daničić where it is visible (at least in doublet versions).

The accent of the verb in contemporary Bosnian dictionaries displays discrepancies and lack of systematicity. Consequently, certain doublet forms should be revised. A comprehensive contrastive-comparative analysis of Bosnian, Croatian, Montenegrin, Serbian and Serbo-Croatian and accentual

${ }^{29}$ Compare present tense forms in which there is a short rising accent: $\dot{o} p r o \bar{b} b \bar{a}$ 'trying', 'tries', zàvìka 'shouting', 'shouts'; instead of the aorist short falling accents: öprōbā/ôprōba 'tried', zävikä/zävika 'shouted'.

${ }^{30}$ There is an interesting interference and similarity in relationships between bèrem 'I pluck', pèrem 'I wash' vs. bërēm 'I pluck', përēm 'I wash' and obàsja 'illuminated', preùda 'remarried' vs. öbasjā/öbasja 'illuminated', prëudā/prëuda 'remarried'. 
patterns (foremost in dictionaries and other normative sources) would be very beneficial and would facilitate comparison with Vuk-Daničić's system.

\section{Abbreviations}

RBF: Halilović Senahid, Palić Ismail, ŠEHović Amela (2010). Rječnik bosanskoga jezika. Sarajevo: Filozofski fakultet u Sarajevu.

RBI: ČEDIĆ Ibrahim (ed.) (2010). Rječnik bosanskog jezika. 2nd ed. Sarajevo: Institut za jezik.

RBJ: JAHIć Dževad (2010-2019). Rječnik bosanskog jezika. Vol. 1-7. Sarajevo: Bošnjačka asocijacija.

BHDK: Bosanskohercegovački dijalekatski kompleks (1975-1986), archive, Sarajevo: Intitut za jezik i književnost.

\section{References}

Alıć Elmedina (2017). Akcenat u standardnom bosanskom jeziku. Sarajevo: Slavistički komitet.

BeLIć Aleksandar (1971). Savremeni srpskohrvatski književni jezik. Prvi deo. Glasovi $i$ akcenat. Beograd: Naučna knjiga.

Bulıć Refik (1999). Akcenat prezimena. In Bosanski jezik u praksi i normi, Refik Bulić (ed.). Tuzla: Printcom.

Bulıć Refik (2009). Rječnik prvopisnih, obličkih i akcenatskih nedoumica u standardnome bosanskom jeziku. Tuzla: Bosanska riječ.

ČIrgić Adnan, ŠušAnj Jelena (2013). Akcenatski savjetnik. Podgorica: Ministarstvo prosvjete.

DANıčıć Đuro (1925). Srpski akcenti. Beograd-Zemun: Srpska kraljevska akademija.

DelAš Helena (2013). Hrvatska preskriptivna akcentologija. Zagreb: Pergamena.

Franks Steven (2017). Syntax and Spell-out in Slavic. Bloomington, IN: Slavica Publishers. HoDžıć Jasmin (2014). Prozodijska obilježja imenica na primjeru televizijske drame Hasanaginica (1983), Književni jezik 25(1-2), 165-185.

HoDžIĆ Jasmin (2016). Metode brzog i uspješnog učenja prozodijskog sistema bosanskog standardnog jezika. Časopis Istraživanja, 115-129.

HoDžIć Jasmin (2017). Akcenat glagola u sarajevskom govoru u odnosu na mostarski govor i bosanski standardni jezik. Časopis Forum Bosnae 78-79, 203-212.

HoDžić Jasmin (2019). Pitanje akcenta ličnih imena u ortoepskoj normi bosanskog jezika. Književni fezik 30, 109-139.

HoDžić Jasmin, ĆATOvić Haris (2018). Ortoepska vrijednost imenica s refleksom dugog jata u savremenom bosanskom jeziku. Proceedings of the International Conference in Linguistics "The History of the World of Languages: Present and Future (Issues)", 127-137. Skopje: Institute of Macedonian Language "Krste Misirkov".

JAHIć Dževad (2000). Fonetika i fonologija. In Gramatika bosanskogo jezika, Dževad JAHIĆ, Senihad Halilović, Ismail PALIĆ, 83-173. Zenica: Dom štampe. 
Jonke Ljudevit (1965). Književni jezik u teoriji i praksi. Zagreb: Znanje.

KADIć Safet (2014). O krivotvorinama imenâ - Original i repríza amidže Idríza. In Bosanski jezik između lingvocida i lingvosuicida (sociolingvistički eseji i ogledi), Safet KADIĆ (ed.), 417-430. Tešanj: Planjax komerc.

KALAJDžIJA Alen (2009). Nedosljednost prenošenja silaznih naglasaka na proklitike u morfološkim i leksičkim kategorijama. Bošnjački pogledi na odnose između bosanskog, hrvatskog i srpskog jezika, 373-385. Sarajevo: Institut za jezik.

KAPOvić Mate (2018). Povijest glagolske akcenuacije u štokavskom (i šire). Rasprave. Časopis Instituta za Hrvatski Jezik i Jezikoslovlje 44(1), 159-285.

KLImENTIĆ Edina (2011). Distribucija silaznih akcenata u gramatikama bosanskog, hrvatskog i srpskog jezika. Istraživanja 6, 93-106.

MARTinović Blaženka (2014). Na putu do naglasne norme. Zagreb: Hrvatska sveučilišna naklada - Sveučilište Jurja Dobrile u Puli.

MATIJAŠić Fahra (1964). Akcenat glagola u savremenom mostarskom govoru u odnosu na Vukov i Daničićev sistem. Južnoslavenski Filolog 26(1-2), 337-368.

Meco Zenaida (2009). Silazni akcenti i dužine u bosanskom jeziku - norma i stvarno stanje. In Zbornik radova sa međunarodnog slavističkog naučnog skupa: Njegoševi dani 1, Tatjana BEČAnović, Rajka GlušicA, Milena Ivanović (eds.), 407-419. Nikšić: Univerzitet Crne Gore, Filozofski fakultet.

PeCo Asim (1987). Vuk-Daničićevi akcenatski principi i naša standardna prozodijska norma. In Iz jezičke teorije i prakse, Asim PeCo (ed.) 236-241. Beograd: Naučna knjiga.

Peco Asim (1988). Osnovi akcentologije srpskohrvatskog jezika. Četvrto izdanje. Beograd: Naučna knjiga.

Peco Asim (2007). Govori istočne i centralne Hercegovine. Izabrana djela I-IV, Vol. I. Sarajevo: Bosansko filološko društvo.

PranjKović Ivo (2010). Za demokratizaciju hrvatske ortoepske norme. In Ogledi o jezičnoj pravilnosti, Ivo PrANJKović (ed.), 17-25. Zagreb: Disput.

RiĐAnović Midhat (2012). Bosnian for Foreigners: With a Comprehensive Grammar. Sarajevo: Rabic.

RiĐANović Midhat, Aljović Nadira (2009). On the shift of Bosnian accent from host to proclitic: New insights. In A Linguist's Linguist: Studies in South Slavic Linguistics in Honor of E. Wayles Browne, Steven Franks, Vrinda Chidambaram, Brian Joseph (eds.), 387-402. Bloomington, IN: Slavica Publishers.

ŠEHović Amela (2013). Mijene akcenatske norme savremenog bosanskog jezika. Književni Jezik 24(1-2), 113-120.

TALIĆ Aida (2015a). Syntactic mobility of the host and accent shift to proclitics. North East Linguistic Society (NELS) 45(3), 117-130.

TALIĆ Aida (2015b). On clitics, their place in the prosodic structure and accent. Formal Approaches to Slavic Linguistics (FASL) 23, 322-341.

Telebak Milorad (2009). Muzika riječi. Ka govornoj kulturi. Banja Luka: Republički pedagoški zavod.

Tošović Branko, Wonisch Arno (eds.) (2009). Bošnjački pogledi na odnose između bosanskog, hrvatskog i srpskog jezika. Sarajevo: Institut za jezik.

VAlJevac Naila (2005). Standardna novoštokavština i jezička situacija u Bosni i Hercegovini. In Radovi XVII: Standardna novoštokavština i bosanskohercegovačka jezička situacija, 4-112. Sarajevo: Institut za jezik. 
VAlJeVAc Naila (2009a). Bosanski standardni jezik i njegova prozodijska norma. In Tošović, Wonisch (eds.), 351-371. Sarajevo: Institut za jezik.

VALJEVAC Naila (2009b). Akcenatske sličnosti i razlike između bosanskog, hrvatskog i srpskog jezika s posebnim osvrtom na jezik u BiH. In Tošović, Wonisch (eds.), 307-349. Sarajevo: Institut za jezik.

Vuković Jovan (1972). Srpskohrvatska književna akcentuacija i funkcionalnost akcenata i kvantiteta. Književni fezik 12, 47-63.

ZEC Draga (2005). Prosodic differences among function words. Phonology 22, 77-112.

Jasmin Hodžić

Language Institute, University of Sarajevo

Hasana Kikića 12, 71000 Sarajevo

Bosnia and Herzegovina

jasmin.hodzic[at]izj.unsa.ba 
